\title{
Ultrasonografía en el primer trimestre
}

\author{
María Paula Tiscornia ${ }^{1,2}$ \\ 1 Encargada del Departamento de Imágenes de la Mujer y el Niño del \\ Servicio de Diagnóstico por Imágenes, Sanatorio Allende, Córdoba, \\ Argentina. \\ 2 Jefe de Trabajos Prácticos de la Cátedra de Diagnóstico por Imágenes \\ de la Universidad Católica de Córdoba, Córdoba, Argentina.
}

Rev Argent Radiol 2019;83:137-138.

\section{Jacques S. Abramowicz}

Ultrasonografía en el primer trimestre. Ediciones Journal, Buenos Aires, Argentina, 2019

(ISBN 9789874922069)

Ultrasonografía en primer trimestre es un libro que reúne, de la mano del autor principal, a numerosos profesionales de los centros más reconocidos de Estados Unidos y Canadá.

Se trata de un libro que, a lo largo de 21 capítulos, trata de manera completa, sencilla y práctica todos los temas que se relacionan al primer trimestre del embarazo y otros temas asociados.

Cada uno de los capítulos cuenta con detalladas descripciones técnicas y anatómicas, como así también de las patologías y alteraciones que se van a tratar. Además de describir el estudio ultrasonográfico, menciona los estudios complementarios que se asocian y son necesarios en cada tema.

Además, aporta un resumen de los componentes clave de las guías y recomendaciones confeccionadas por las sociedades y organizaciones más importantes a nivel mundial, como la Sociedad Internacional de Ultrasonido en Ginecología y Obstetricia (ISUOG, por su sigla en inglés), el Colegio Estadounidense de Obstetras y Ginecólogos (ACOG, por su sigla en inglés), y el Instituto Americano para Ultrasonido en Medicina (AIUM, por su sigla en inglés), entre otras.

No solo estudia el primer trimestre del embarazo, sino también aspectos técnicos y de bioseguridad diagnóstica en ese período reconocidamente vulnerable, además de patologías asociadas, maternas o fetales.

También estudia otros temas relacionados, como la ecografía en la infertilidad, sumamente importante dado el gran desarrollo de nuevos tratamientos de fertilidad y alternativas de concepción.

En algunos capítulos, se expide sobre temas particularmente actuales y de importante perspectiva futura,
Address for correspondence María Paula Tiscornia, (e-mail: drapaulatis@hotmail.com).

como las imágenes volumétricas tridimensionales (3D) y el intervencionismo fetal.

De manera muy práctica, al final de cada capítulo existe un resumen del mismo y una revisión corta de los aspectos más importantes de cada uno a modo de ítems, denominados "puntos de enseñanza."

Es de destacar que se utilizan muchas imágenes de alta calidad que permiten apreciar claramente lo que se describe en el texto. De la misma manera, existen gráficos e ilustraciones explicativas, principalmente en el capítulo sobre embriología, que hacen mucho más amena la lectura.

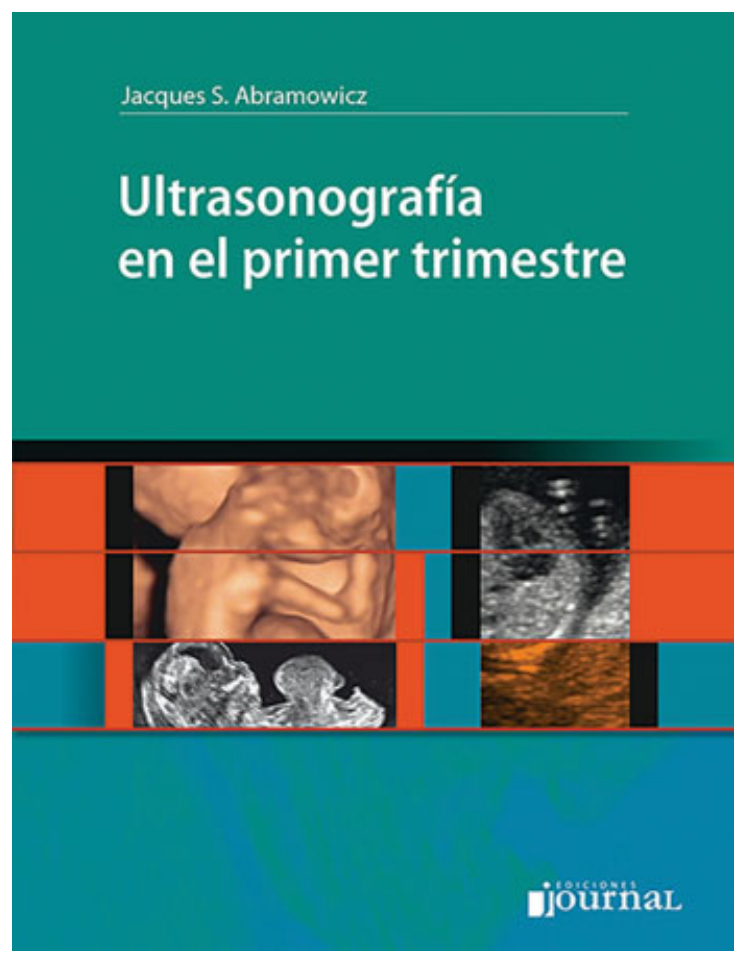

DOI https://doi.org/ 10.1055/s-0039-1696695. ISSN 1852-9992.
Copyright @ $\odot$ 2019, Sociedad Argentina de Radiología. Publicado por Thieme Revinter Publicações Ltda., Rio de Janeiro, Brazil. Todos los derechos reservados.

\section{License terms}

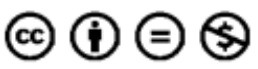

